\title{
Effect of Organic, Inorganic and Bio-Fertilizer on Growth, Flowering, Yield and Quality of Strawberry (Fragaria $\times$ Ananassa Duch.) cv. Chandler
}

\author{
Karma Beer $^{1 *}$, Santosh Kumar ${ }^{2}$, Alok K. Gupta ${ }^{3}$, M.M. Syamal ${ }^{2}$ \\ ${ }^{1}$ ICAR- Indian Institute of Soil and Water Conservation, \\ Research Center, Koraput Odisha, India \\ ${ }^{2}$ Department of Horticulture, Institute of Agricultural Sciences, \\ Banaras Hindu University, Varanasi-221 005, India \\ ${ }^{3}$ National Research Centre (NRC) on Litchi, Muzaffarpur, Bihar, India \\ *Corresponding author
}

\section{A B S T R A C T}

\begin{tabular}{l} 
Ke y w o r d s \\
$\begin{array}{l}\text { Bio-fertilizer, } \\
\text { Growth, } \\
\text { Flowering, } \\
\text { Yield, } \\
\text { Strawberry. }\end{array}$ \\
\hline Article Info \\
\hline $\begin{array}{l}\text { Accepted: } \\
26 \text { April } 2017 \\
\text { Available Online: } \\
10 \text { May } 2017\end{array}$ \\
\hline
\end{tabular}

An experiment was carried out during the two subsequent year i.e. 2010-11 and 2011-12 to study the effect of organic, inorganic and bio-fertilizer on vegetative growth, flowering and yield of strawberry cv. Chandler. There were fourteen treatments replicated thrice in randomized block design. Treatments comprise different levels of organic, inorganic and bio-fertilizers at diverse combination. All the doses of organic, inorganic and bio-fertilizers were applied at time of planting. The data of both the years of experiment were pooled and analyzed. Plant height, number of leaves per plant, runners per plant and number of crown per plant was found maximum in treatment (T14). Minimum number of days taken to produce first flower and minimum fruit set was found in treatment (T13), while maximum number of flowers per plant, number of fruit set per plant and duration of harvesting was recorded in treatment (T13). Fruiting characteristics and quality parameters were found superior in treatment (T13). As for as yield is concerned it was noted that treatment (T13) produced maximum yield, whereas minimum yield was recorded in untreated plants i.e. control.

\section{Introduction}

Cultivated strawberry (Fragaria $\times$ ananassa Duch.) is an octoploid species $(2 \mathrm{n}=8 \mathrm{x}=56)$ belonging to the genus Fragaria of the family Rosaceae. The modern cultivated strawberry arose in Europe in the 18th century as a chance cross between two American native species, $F$. virginiana and $F$. chiloensis. It is herbaceous crop with prostate growth habit, which behaves as an annual in sub-tropical region and perennial in temperature region.
Strawberry fruits are attractive with distinct pleasant aroma and flavour, consumed as dessert and also have a special demand by the fruit processing units for the preparation of jams, ice cream, syrups, etc. Characteristic aroma in strawberries is due to presence of volatile esters. It is one of the important fruit in the world. It has become favorite fruit crop among the Indian growers near towns and cities, because of its remunerative prices and 
higher profitability, which has resulted a phenomenal increase in its area and production in the recent years (Sharma and Sharma, 2004; Sharma et al., 2006). The application of synthetic fertilizers has improved yield per unit area manifold but these fertilizers are expensive and hamper the ecological balance of the soil.

The balanced application of organic manure, biofertilizers incorporated with inorganic fertilizers to get higher production. Biofertilizers are the organisms that enrich the nutrient quality of soil. Plants have a number of beneficial relationships with such organisms. Nutrient status of the soil is most important factor affecting the productivity of strawberry crops. The beneficial microorganisms used as biofertilizers increase the growth of plants either by enhancing the availability of nutrients, releasing plant growth stimulating hormones. Biofertilizers are gaining increased attention to improve soil fertility and quality production of horticultural crops, due to hike in prices of chemical fertilizers and to minimize environmental pollution (Sindhu et al., 2010). Modern day intensive crop cultivation results the huge application of chemical fertilizers which are not only in short supply but also expensive and pollute the environment, soil and water too. Therefore, the current emphasis is being given to explore the possibilities of supplementing the chemical fertilizers with organic fertilizers particularly bio-fertilizer of microbial origin.

\section{Materials and Methods}

\section{Experimental site}

The experiment was conducted at the Horticulture Research Farm near central office, Institute of Agricultural Sciences, Department of Horticulture, Banaras Hindu University, Varanasi (U.P.), India during two subsequent years i.e. 2010-11 and 2011-12.
Varanasi is situated in eastern part of Utter Pradesh, which lies between $25^{\circ} 19^{\prime} 59^{\prime \prime}$ North latitude and $83^{\circ} 00^{\prime} 00^{\prime \prime}$ East longitude at an elevation of $183.5 \mathrm{~m}$ above from mean sea level.

\section{Climatic and weather condition}

The climatic condition of Varanasi is subtropical with three distinct seasons i.e. winter, summer and rainy. During the winter months (December-January) temperature falls to $5^{\circ} \mathrm{C}$ $8^{\circ} \mathrm{C}$ or even low. Occasional spell of frost and precipitation may be during winters. Most of the rainfall is received in the middle of July to end of September after which the intensity of rainfall decreases. The mean annual rainfall is about 850-1100 $\mathrm{mm}$.

\section{Experimental field preparation}

The experimental plot was well prepared by repeated ploughing followed by planking to obtain a fine tilth. All the weeds, grasses/plant residues and other materials were removed from the field followed by planking. Raised beds of $15 \mathrm{~cm}$ in height were prepared for planting of $\mathrm{Cv}$. Chandler's runners at row to row $60 \mathrm{~cm}$ and plant to plant $25 \mathrm{~cm}$. Weeding and hoeing was done manually with the help of khurpi. It is done after light irrigation in order to loosen the soil which facilitates weeding and hoeing. Weeding was done to keep the plots clean, pulverized and adequately aerated. First weeding was done after 30 days of transplanting, second weeding after 50 days of transplanting and later on as when required.

\section{Details of experiment}

\section{Technical programme}

The experiment was conducted at Horticulture Research Farm, Banaras Hindu University, Varanasi with Azotobacter 6 and $7 \mathrm{~kg} \mathrm{ha}^{-1}$ (Biofertilizers) and vermicompost 25 and 30 
ton $\mathrm{ha}^{-1}$ (Organic manure) respectively, which were supplemented with inorganic fertilizers (DAP and MOP) to balance fertilizer requirement of strawberry at different level of the treatment.

Treatment combination of fourteen different treatments combined with organic, inorganic and mulching are T0: Control, T1: Mulching + Azotobactor (6 kg ha-1), T2: Mulching + Azotobactor (7 $\left.\mathrm{kg} \mathrm{ha}^{-1}\right)$, T3: Mulching + Vermicompost (25 ton ha $\left.{ }^{-1}\right)$, T4: Mulching + Vermicompost (30 ton $\mathrm{ha}^{-1}$ ), T5: Mulching + NPK (0:80:80 kg ha $\left.{ }^{-1}\right)$, T6: Mulching + NPK (80:100:100 kg ha $\left.{ }^{-1}\right)$, T7: Azotobactor $(6 \mathrm{~kg}$ $\left.\mathrm{ha}^{-1}\right)+$ Vermicompost (25 ton $\left.\mathrm{ha}^{-1}\right)$, T8: Azotobactor (7 kg ha $\left.{ }^{-1}\right)+$ Vermicompost (30 ton ha $\left.{ }^{-1}\right)$, T9: Azotobactor $\left(6 \mathrm{~kg} \mathrm{ha}^{-1}\right)+\mathrm{NPK}$ (70:80:80 kg ha $\left.{ }^{-1}\right)$, T10: Azotobactor $(7 \mathrm{~kg} \mathrm{ha}$ $\left.{ }^{1}\right)+\operatorname{NPK}\left(80: 100: 100 \mathrm{~kg} \mathrm{ha}{ }^{-1}\right), \quad \mathrm{T} 11:$ Vermicompost $\left(25\right.$ ton $\left.\mathrm{ha}^{-1}\right)+$ NPK $(70: 80: 80$ $\left.\mathrm{kg} \mathrm{ha}^{-1}\right)$, T12: Vermicompost $\left(30\right.$ ton $\left.\mathrm{ha}^{-1}\right)+$ NPK $\quad\left(80: 100: 100 \quad \mathrm{~kg} \quad \mathrm{ha}^{-1}\right), \quad$ T13: Vermicompost (25 ton ha $\left.{ }^{-1}\right)+$ Azotobactor (6 $\left.\mathrm{kg} \mathrm{ha}{ }^{-1}\right)+\operatorname{NPK}\left(70: 80: 80 \mathrm{~kg} \mathrm{ha}^{-1}\right)$, T14: Vermicompost (30 ton $\left.\mathrm{ha}^{-1}\right)+$ Azotobactor (7 $\left.\mathrm{kg} \mathrm{ha}{ }^{-1}\right)+\operatorname{NPK}\left(80: 100: 100 \mathrm{~kg} \mathrm{ha}^{-1}\right)$ and observations were recorded on plant height (cm), number of leaves per plant, number of runner per plant, number of crowns per plant, days taken to produce first flower, number of flower per plant, number of days taken to first fruit set, number of fruit set per plant, duration of harvesting and yield per plant in grams $(\mathrm{g})$.

\section{Statistical analysis}

The data recorded during the course of investigation was subjected to statistical analysis described by Panse and Sukhatme (1985). The significance and non-significance of treatment effect was judge with the help of ' $F$ ' (variance ratio) table. The significance differences between the mean were tested against the critical difference at 5\% probability level.

\section{Results and Discussion}

\section{Growth characters}

From table 1 it is clear that plant height $(23.91 \mathrm{~cm})$ and number of leaves per plant (65.37) were obtained maximum in vermicompost (30 ton/ha) + Azotobacter (7 $\mathrm{kg} / \mathrm{Ha})+\mathrm{NPK}(80: 100: 100)$ treated plants. The increase in vegetative growth characters under these treatments might be due to increase nitrogen availability to the plants through vermicompost. Application of inorganic fertilizers and bio-fertilizers along with organic manures increased the available NPK status, organic $\mathrm{C}$ and microbial biomass and dehydrogenase activity and hence they help in increasing height and spread of the plant. Similar results also reported by Hazarika (2011) in banana and Tripathi et al.,(2010) in strawberry. Rana and Chandel (2003) also support the findings that the nitrogen integration using combination of inorganic $\mathrm{N}$ and Azotobacter inoculation produced maximum plant height and number of leaves in strawberry.

Table 1 clearly revealed that number of crowns and runners per plant were significantly increased with the application of organic, inorganic and biofertilizers at different levels. Maximum number of runners (7.87) and maximum number of crown per plant (8.25) were significantly reported in vermicompost (30 ton/ha) + Azotobacter (7 $\mathrm{kg} / \mathrm{ha})+\mathrm{NPK}(80: 100: 100 \mathrm{~kg} / \mathrm{ha})$ treated plant. Increase in number of runners per plant might be due to increased growth of plant in the form of height and number of leaves, which accumulated more photosynthates and thereby increased runners and leaf area per plant. These findings are in complete agreement with Umar et al., (2009) in strawberry who narrated highest runners per plant with PM + Azotobacter + wood ash + vermicompost + oil cake application. 


\section{Floral characters}

It is clear from table 2 that minimum number of days taken to produce first flower (49.41 days) and maximum number of flowers per plant was recorded in vermicompost (25 ton/ha) + Azotobacter $(6 \mathrm{~kg} / \mathrm{Ha})+\mathrm{NPK}$ (70:80:80) treated plants. This phenomenon may be on account of prolonged growth of plant in the presence of organic, inorganic and biofertilizers. These results gain support from the findings of Tripathi et al., (2015), who observed earliest flowering with vermicompost + Azotobacter which are also in close conformity with the findings of Kumar et al., (2007) in tomato. Data presented in table 2 clearly revealed that minimum number of days taken to fruit set (6.26) and maximum number of fruits set per plant (42.09) was recorded in plants treated with vermicompost (25ton/ha) + Azotobacter $(6 \mathrm{~kg} / \mathrm{Ha})+\mathrm{NPK}(70: 80: 80)$ treated plants.

The earliness may be due to an optimum supply of plant nutrients and growth hormones in right amount during the entire crop period which induces the vegetative development of plant and ultimately more photosynthesis. Similar findings also reported by Yadav et al., (2010) and Umar et al., (2010) in strawberry. These results are in conformity with the finding of Tripathi et al., (2015) who noted that increase in vermicompost and Azotobacter doses resulted in maximum fruit set in strawberry.

From table 2 it is clear that duration of harvesting was observed maximum when the plants were treated with vermicompost (25 ton/ha) + Azotobacter (6 kg/Ha) + NPK (70:80:80). Similar results were also recorded by Hazarika et al., (2011) and Singh and Singh (2009) in strawberry, who observed advanced earliness by approximately one month which obviously extended the period of harvesting.

\section{Fruit characteristics}

Relevant data pertaining to fruit characteristics are presented in table 3 clearly revealed that vermicompost $\left(25\right.$ ton $\left.\mathrm{ha}^{-1}\right)+$ Azotobacter $\left(6 \mathrm{~kg} \mathrm{ha}^{-1}\right)+\mathrm{NPK}(70: 80: 80 \mathrm{~kg}$ $\left.\mathrm{ha}^{-1}\right)$ treated plants produced maximum berry length $(4.83 \mathrm{~cm})$, maximum berry width $(2.71 \mathrm{~cm})$, higher fruit volume $(6.58 \mathrm{cc})$ and maximum berry weight (10.96 g) which was significantly superior over the other treatments. This increase in fruit size and weight during the present investigation might be due to the increased photosynthetic ability of plants fertilized with vermicompost, Azotobacter and inorganic fertilizer, which in turn might have favored an increased accumulation of dry matter. Fruit size, weight and berry volume are highly correlated with dry matter content and application of organic and inorganic fertilizers might have balance the level of hormone and nitrogen fixers known for accumulation of dry matter and their translocation (Kachot et al., 2001) as well as synthesis of different growth regulators (Awasthi et al., 1998). Similar results were obtained by Yadav et al., (2010) and Shukla et al., (2009) in tomato.

\section{Quality attributes}

From table 4 the maximum TSS (9.39 0Brix) and total sugars $(8.59 \%)$ contents were recorded in the berries produced from the plants supplied with vermicompost (25 ton/ha) + Azotobacter (6 $\mathrm{kg} / \mathrm{Ha})+\mathrm{NPK}(70: 80: 80)$. An increase in TSS and total sugars contents with Azotobacter, NPK and vermicompost application might be due to the quick metabolic transformation of starch and pectin into soluble compounds and rapid translocation of sugars from leaves to the developing fruits. These findings are in agreement with the results of Singh et al., (2009) in ber and Attia et al., (2009) in banana. The maximum titratable acidity $(0.76 \%)$ was recorded in the berries which were produced from the untreated plants, whereas the minimum acidity $(0.57 \%)$ was recorded 
Table.1 Effect of organic, inorganic and bio-fertilizer on growth characteristics of strawberry

\begin{tabular}{|c|c|c|c|c|c|c|c|c|c|c|c|c|c|c|c|c|}
\hline $\begin{array}{l}\text { Treatments } \\
\text { Plant height }(\mathrm{cm})\end{array}$ & $\begin{array}{c}\mathbf{T}_{\mathbf{0}} \\
11.13\end{array}$ & $\begin{array}{c}\mathbf{T}_{1} \\
13.94\end{array}$ & $\begin{array}{c}\mathbf{T}_{\mathbf{2}} \\
12.33\end{array}$ & $\begin{array}{c}\mathbf{T}_{\mathbf{3}} \\
14.31\end{array}$ & $\begin{array}{c}\mathbf{T}_{\mathbf{4}} \\
14.29\end{array}$ & $\begin{array}{c}\mathbf{T}_{5} \\
15.15\end{array}$ & $\begin{array}{c}\mathbf{T}_{\mathbf{6}} \\
17.74\end{array}$ & $\begin{array}{c}\mathbf{T}_{7} \\
12.59\end{array}$ & $\begin{array}{c}\mathbf{T}_{\mathbf{8}} \\
12.92\end{array}$ & $\begin{array}{c}\mathbf{T}_{\mathbf{9}} \\
15.69\end{array}$ & $\begin{array}{c}\mathbf{T}_{\mathbf{1 0}} \\
20.63\end{array}$ & $\begin{array}{c}\mathbf{T}_{\mathbf{1 1}} \\
21.97\end{array}$ & $\begin{array}{c}\mathbf{T}_{\mathbf{1 2}} \\
22.47\end{array}$ & $\begin{array}{c}\mathbf{T}_{\mathbf{1 3}} \\
23.27\end{array}$ & $\begin{array}{c}\mathbf{T}_{\mathbf{1 4}} \\
23.91\end{array}$ & $\begin{array}{c}\text { CD at } \mathbf{5 \%} \\
2.38\end{array}$ \\
\hline Number of leaves per plant & 36.60 & 40.01 & 38.47 & 40.89 & 42.58 & 50.2 & 57.32 & 44.19 & 47.53 & 56.81 & 62.12 & 59.11 & 62.12 & 64.43 & 65.37 & 2.59 \\
\hline Runners per plant & 3.51 & 4.25 & 4.55 & 4.63 & 3.91 & 5.10 & 5.33 & 4.86 & 5.18 & 5.23 & 5.76 & 5.38 & 6.41 & 7.15 & 7.87 & 1.22 \\
\hline Crown per plant & 3.27 & 3.91 & 4.59 & 5.45 & 5.31 & 6.74 & 7.03 & 6.31 & 6.94 & 7.02 & 7.37 & 6.82 & 7.34 & 7.98 & 8.25 & 0.96 \\
\hline
\end{tabular}

Table.2 Effect of organic, inorganic and bio-fertilizer on flowering characteristics of strawberry

\begin{tabular}{|c|c|c|c|c|c|c|c|c|c|c|c|c|c|c|c|c|}
\hline $\begin{array}{c}\text { Treatments } \\
\text { Days Taken To First Fruit Set }\end{array}$ & $\begin{array}{c}\mathbf{T}_{\mathbf{0}} \\
9.45\end{array}$ & $\begin{array}{c}\mathbf{T}_{\mathbf{1}} \\
8.64\end{array}$ & $\begin{array}{c}\mathbf{T}_{2} \\
8.51\end{array}$ & $\begin{array}{c}\mathbf{T}_{3} \\
8.76\end{array}$ & $\begin{array}{c}\mathbf{T}_{\mathbf{4}} \\
8.35\end{array}$ & $\begin{array}{c}\mathbf{T}_{\mathbf{5}} \\
7.88\end{array}$ & $\begin{array}{c}\mathbf{T}_{6} \\
7.81\end{array}$ & $\begin{array}{c}\mathbf{T}_{7} \\
8.19\end{array}$ & $\begin{array}{c}\mathbf{T}_{\mathbf{8}} \\
8.06\end{array}$ & $\begin{array}{c}\mathbf{T}_{\mathbf{9}} \\
7.08\end{array}$ & $\begin{array}{r}\mathbf{T}_{\mathbf{1 0}} \\
7.03\end{array}$ & $\begin{array}{r}\mathbf{T}_{11} \\
6.71\end{array}$ & $\begin{array}{c}\mathbf{T}_{12} \\
6.77\end{array}$ & $\begin{array}{c}\mathbf{T}_{13} \\
6.26\end{array}$ & $\begin{array}{c}\mathbf{T}_{14} \\
6.73\end{array}$ & $\begin{array}{c}\text { CD at 5\% } \\
0.54\end{array}$ \\
\hline Number Of Fruit Set Per Plant & 26.2 & 30.49 & 33.73 & 34.77 & 36.72 & 38.63 & 36.81 & 39.06 & 37.26 & 37.7 & 38.39 & 41.51 & 37.67 & 42.09 & 41.45 & 4.05 \\
\hline Duration Of Harvesting & 50.82 & 54.66 & 55.93 & 64.18 & 64.88 & 65.88 & 67.12 & 64.02 & 62.24 & 65.02 & 65.7 & 69.01 & 70.89 & 73.87 & 71.75 & 4.75 \\
\hline Days to Produced first flower & 65.77 & 62.98 & 63.21 & 61.59 & 61.33 & 61.31 & 57.56 & 60.65 & 61.51 & 59.8 & 57.71 & 56.85 & 56.56 & 51 & 59.53 & 5.06 \\
\hline Number of Flowers Per Plant & 41.34 & 44.3 & 46.74 & 47.66 & 48.64 & 62.75 & 63.72 & 56.02 & 58.13 & 64.1 & 63.32 & 63.94 & 65.05 & 66.36 & 66.11 & 5.76 \\
\hline
\end{tabular}

Table.3 Effect of organic, inorganic and bio-fertilizer on fruiting characteristics of strawberry

\begin{tabular}{|c|c|c|c|c|c|c|c|c|c|c|c|c|c|c|c|c|}
\hline Treatments & $\mathbf{T}_{\mathbf{0}}$ & $\mathbf{T}_{1}$ & $\mathbf{T}_{2}$ & $\mathbf{T}_{3}$ & $\mathbf{T}_{4}$ & $\mathbf{T}_{5}$ & $T_{6}$ & $\mathbf{T}_{7}$ & $\mathbf{T}_{8}$ & $\mathbf{T}_{9}$ & $\mathbf{T}_{10}$ & $\mathbf{T}_{11}$ & $\mathbf{T}_{12}$ & $\mathbf{T}_{13}$ & $\mathbf{T}_{14}$ & CD at $5 \%$ \\
\hline berry length & 2.12 & 2.18 & 2.51 & 2.59 & 3.00 & 3.23 & 3.87 & 3.19 & 3.35 & 3.50 & 3.98 & 3.84 & 4.44 & 4.92 & 4.63 & 0.35 \\
\hline berry width & 1.08 & 1.18 & 1.20 & 1.29 & 1.41 & 1.64 & 1.75 & 1.67 & 1.79 & 2.12 & 2.39 & 2.20 & 2.54 & 2.78 & 2.71 & 0.04 \\
\hline berry weight & 4.26 & 4.60 & 5.88 & 6.60 & 7.00 & 7.57 & 8.22 & 7.26 & 7.43 & 8.72 & 9.32 & 9.31 & 9.96 & 10.58 & 9.86 & 0.42 \\
\hline berry volume & 3.18 & 3.32 & 3.62 & 3.91 & 4.05 & 4.28 & 4.93 & 3.98 & 4.15 & 5.38 & 5.27 & 5.52 & 6.15 & 6.79 & 6.02 & 0.31 \\
\hline
\end{tabular}

Table.4 Effect of organic, inorganic and bio-fertilizer on yield and quality parameters of strawberry

\begin{tabular}{|c|c|c|c|c|c|c|c|c|c|c|c|c|c|c|c|c|}
\hline Treatments & $\overline{T_{0}}$ & $\mathbf{T}_{1}$ & $\overline{T_{2}}$ & $\mathbf{T}_{3}$ & $\mathbf{T}_{4}$ & $\mathbf{T}_{5}$ & $T_{6}$ & $\overline{T_{7}}$ & $\mathbf{T}_{8}$ & $\mathbf{T}_{9}$ & $\mathbf{T}_{10}$ & $\mathbf{T}_{11}$ & $\mathbf{T}_{12}$ & $\mathbf{T}_{13}$ & $\mathbf{T}_{14}$ & CD at $5 \%$ \\
\hline TSS & 6.27 & 6.39 & 6.22 & 6.55 & 6.50 & 6.78 & 7.39 & 7.10 & 7.15 & 7.40 & 8.15 & 7.69 & 8.64 & 9.39 & 8.82 & 1.03 \\
\hline Acidity & 0.76 & 0.74 & 0.74 & 0.71 & 0.71 & 0.67 & 0.68 & 0.67 & 0.68 & 0.66 & 0.63 & 0.63 & 0.65 & 0.62 & 0.57 & 0.075 \\
\hline Total Sugar & 6.07 & 6.47 & 6.55 & 6.83 & 7.07 & 7.33 & 7.14 & 7.30 & 7.22 & 7.69 & 7.73 & 8.05 & 8.10 & 8.59 & 8.3 & 0.35 \\
\hline Ascorbic Acid & 47.85 & 47.62 & 48.39 & 48.72 & 48.97 & 49.96 & 50.95 & 49.82 & 50.22 & 50.56 & 52.27 & 52.48 & 53.31 & 54.36 & 54.98 & 1.895 \\
\hline Yield Per Plant & 120.24 & 128.48 & 141.38 & 151.73 & 164.54 & 230.87 & 249.35 & 177.74 & 180.85 & 241.86 & 270.77 & 254.75 & 308.52 & 335.82 & 331.18 & 9.31 \\
\hline
\end{tabular}


Table.5 Correlation coefficient values of growth and yield attributing characters with yield

\begin{tabular}{llllll}
\hline & $\begin{array}{l}\text { Plant height } \\
(\mathrm{cm})\end{array}$ & $\begin{array}{l}\text { Number of } \\
\text { leaves per } \\
\text { plant }\end{array}$ & $\begin{array}{l}\text { Runners } \\
\text { per plant }\end{array}$ & $\begin{array}{l}\text { Crown } \\
\text { per plant }\end{array}$ & $\begin{array}{l}\text { Yield Per } \\
\text { Plant }\end{array}$ \\
Plant height $(\mathrm{cm})$ & 1 & $0.926^{* *}$ & $0.871^{* *}$ & $0.768^{* *}$ & $0.930^{* * *}$ \\
Number of leaves per plant & & 1 & $0.883^{* *}$ & $0.906^{* *}$ & $0.977^{* *}$ \\
Runners per plant & & & 1 & $0.866^{* *}$ & $0.926^{* *}$ \\
Crown per plant & & & & 1 & $0.906^{* *}$ \\
Yield Per Plant & & & & & 1 \\
\hline
\end{tabular}

Table.6 Correlation coefficient of yield attributing characters and morphological characters of berries with Yield

\begin{tabular}{|c|c|c|c|c|c|}
\hline & $\begin{array}{l}\text { Berry } \\
\text { Length }\end{array}$ & $\begin{array}{l}\text { Berry } \\
\text { Width }\end{array}$ & $\begin{array}{l}\text { Berry } \\
\text { Weight }\end{array}$ & Berry Volume & $\begin{array}{l}\text { Yield Per } \\
\text { Plant }\end{array}$ \\
\hline Berry Length & 1 & $0.966^{* *}$ & $0.970^{* *}$ & $0.964^{* *}$ & $0.976^{* * *}$ \\
\hline Berry Width & & 1 & $0.955^{* *}$ & $0.966^{* *}$ & $0.965^{* *}$ \\
\hline Berry Weight & & & 1 & $0.962^{* *}$ & $0.953^{* *}$ \\
\hline Berry Volume & & & & 1 & $0.971^{* *}$ \\
\hline Yield Per Plant & & & & & 1 \\
\hline
\end{tabular}

Figure.1 Fruit yield and its relationship between numbers of flower per plant

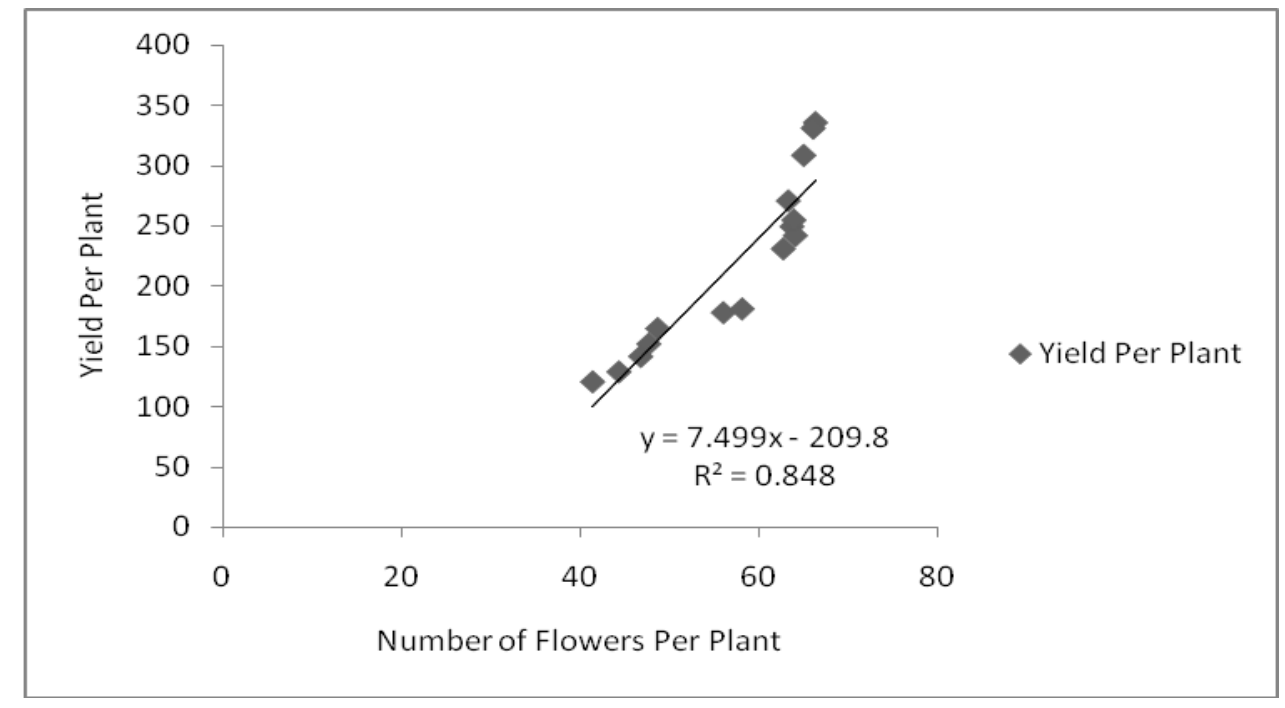

Vermicompost (30 ton/ha) + Azotobacter (7 $\mathrm{kg} / \mathrm{Ha})+\mathrm{NPK}$ (80:100:100). The maximum amount of ascorbic acid content $(54.98 \mathrm{mg} / 100$ $\mathrm{g}$ fresh fruit weight) was recorded in the berries produced from the plants applied with Vermicompost (30 ton/ha) + Azotobacter (7 $\mathrm{kg} / \mathrm{Ha})+$ NPK $(80: 100: 100)$. This result got the support with the findings of Singh et al., (2011) 
in ber and Tripathi et al., (2015) in strawberry. The respective increase in ascorbic acid content might be due to the increased efficiency of microbial inoculants to fix atmospheric nitrogen, increase in availability of phosphorous and secretion of growth promoting substances which accelerates the physiological process like carbohydrates synthesis, etc. The maximum yield per plant $(335.82 \mathrm{~g})$ was recorded in the plants treated with vermicompost (25 ton/ha) + Azotobacter (6 kg/Ha) + NPK (70:80:80). Greater accumulation of dry matter conferred greater ability to produce higher yield. Similar finding were reported by Tripathi et al., (2010) in strawberry.

\section{Estimation of correlation co-efficient}

From table 5 estimates for correlation coefficient for plant height, number of leaves per plant, runner per plant, crown per plant showed highly significant positive correlation with yield. Plant height ( $\mathrm{r}=0.930 * *)$, number of leaves per plant $\left(0.977^{* *}\right)$, runners per plant $(0.926 * *)$ and crown per plant $(0.906 * *)$ shows highly positive correlation among these parameters. Similarly yield was also correlated with yield attributed morphological characters of berries like berry length, berry width, berry weight and berry volume (Table 6). Berry length $\left(0.976^{* *}\right)$, berry width $\left(0.965^{* *}\right)$, berry weight $(0.953 * *)$ and berry volume $(0.971 * *)$ were positively correlated with yield.

\section{Relationship between yield-number of flowers per plant}

A linear relationship between yield-number of flowers per plant of strawberry was observed. Data from figure 1 clearly revealed that when number of flower per plant increases the yield per plant increases linearly. The regression equation (1) obtained from figure 1 showed that; about $84.8 \%$ variation in fruit yield can be explained by number of flowers per plant. The equation also states that, per plant decrease in flowers number the yield also reduced. The regression equation: $\mathrm{y}=7.499 \mathrm{x}-209.8, \mathrm{R}^{2}=0.848, \mathrm{n}=15, \mathrm{p}<0.05$ (1)

\section{Acknowledgments}

We deeply acknowledged to university grand commission (UGC) for proving the fellowship for successful completion of this research.

\section{References}

Attia, M., Ahmed, M.A. and El-Sanbaty, M.R. Use of biotechnologies to increase growth, productivity and fruit quality of Moghrabi banana under different rates of phosphorus. World J. Agril. Sci. 5: 21120 (2009).

Hazarika, T.K, Nautiyal, B.P. and Bhattacharyya, R.K. Effect of INM on productivity and soil characteristics of tissue cultured banana cv. Grand Naine in Mizoram, India. Progressive Horticulture 43: 30-35 (2011).

Kachot, N.A., Malvia, D.D., Solanki, R.M. and Sagrka, B.K., Integrated nutrient management in rainy season groundnut. I. J. Agron., 46: 516-522 (2001).

Kumar, A., Kumar, J. and Babu, R. Effect of inorganic and biofertilizers on growth, yield and quality of tomato. Prog. Agri., 7(1\&2): 151-152 (2007).

Panse, V.G. and Sukhatme, P.V. Statistical Methods for Agricultural Workers, 4th ed., ICAR, New Delhi, 347 p (1985).

Rana, R.K. and Chandel, J.S. Effect of biofertilizers and nitrogen on growth, yield and fruit quality of strawberry. Prog. Hort., 35(1): 25-30 (2003).

Sharma, R.R. and Sharma, V.P. The Strawberry. ICAR, New Delhi, India (2004).

Sharma, R.R., Krishna, H., Patel, V.B., Dahuja, A. and Singh, R. Fruit calcium content and lipoxygenase activity in relation to albinism disorder in strawberry. Sci. Hortic., 107: 150-154 (2006).

Shukla, Y.R., Thakur, A.K. and Joshi, A., Effect of inorganic and biofertilizers on 
yield and horticultural traits of tomato. I. J. Hort., 66(2): 285-287 (2009).

Sindhu, S.S., Nisha, V., Seema, D. and Deepika, C. Biofertilizer application for growth stimulation of horticultural crops. Haryana J. of Horticultural Sci., 39(1/2): 48-70 (2010).

Singh, A. and Singh, J.N. Effect of biofertilizers and bioregulators on growth, yield and nutrient status of strawberry $\mathrm{cv}$. sweet charlie. I. J. Hort., 66(2): 220-224 (2009).

Singh, M., Singh, H.K. and Singh, J.K. Effect of INM on yield and quality of ber cv. Banarsi Karaka. Asian J. Hort., 4(1): $47-$ 49 (2009).

Tripathi, V.K. Sanjeev Kumar and Gupta, A.K. Influence of Azotobacter and Vermicompost on Growth, Yield and Quality of Strawberry Cv. Chandler. Indian J. Horticulture, 72(2): 201-205 (2015)

Tripathi, V.K., Kumar, N., Shukla, H.S. and Mishra, A.N. Influence of Azotobacter, Azospirillum and PSB on growth, yield and quality of strawberry $\mathrm{cv}$. chandler. Abst: National Symposium on Conservation Hort., Dehradun, pp. 198 199 (2010).
Umar, I., Vinod, K.W., Ravi, K., Mahital, J. Effect of FYM, Urea and Azotobacter on growth, yield and quality of strawberry cv. chandler. Not. Bot. Hort. Agrobot. Cluj., 37(1): 139-143 (2009).

Umar, I., Wali, V.K., Rehman, M.U., Mir, M.M., Banday, S.A. and Bisati, I.A. Effect of Subabul (Leucaena Leucocephala), Urea and biofertilizer application on growth, yield and quality of strawberry cv. chandler. Applied Biological Res., 12: 50-54 (2010).

V.K. Tripathi, Sanjeev, K. and Gupta, A.K. Influence of Azotobacter and vermicompost on growth, flowering, yield and quality of strawberry cv. Chandler Indian J. Hort., 72(2): 201-205 (2015).

Yadav, S. Integrated nutrient management studies in subtropical peach cv. saharanpur prabhat under high density system. Ph.D. Thesis, C.S.A. U.A.T., Kanpur, India (2010).

Zargar, M.Y., Baba, Z.A., Sofi, P.A. Effect of $\mathrm{N}, \mathrm{P}$ and biofertilizers on yield and physico-chemical attributes of strawberry. Agri Thesis 6(1): 3-8 (2008).

\section{How to cite this article:}

Karma Beer, Santosh Kumar, Alok K. Gupta and Syamal, M.M. 2017. Effect of Organic, Inorganic and Bio-Fertilizer on Growth, Flowering, Yield and Quality of Strawberry (Fragaria $\times$ Ananassa Duch.) cv. Chandler. Int.J.Curr.Microbiol.App.Sci. 6(5): 2932-2939. doi: https://doi.org/10.20546/ijcmas.2017.605.332 